\title{
COMPARATIVE ANALYTICAL DETERMINATION OF THERMAL PROTECTION BEHAVIOR FOR EXPERIMENTAL MODELS MADE OF STRATIFIED BIOCOMPOSITE BOARDS OF LIGNO-CELLULOSE NATURE
}

\author{
SILVIA - ANDREEA NITU ${ }^{1 *}$, RADU I. IATAN ${ }^{1}$, ION DURBACA ${ }^{1}$, GABRIEL \\ PETROSEL ${ }^{1}$, ELENA SURDU ${ }^{1}$, DANA CLAUDIA FARCAS - FLAMAROPOL ${ }^{1}$ \\ ${ }^{1}$ Polytechnic University of Bucharest, no. 313, Splaiul Independentei, sector 6, Bucharest, \\ 060042, Romania
}

\begin{abstract}
The paper addresses the comparative analytical determination of thermal insulation behavior for various experimental models made of stratified and hybrid biocomposites of ligno-cellulose nature. The analytical determination of the thermal resistance and the overall thermal insulation coefficient for each experimental model is performed using the calculation methodology for energy efficiency. The results obtained after the analysis of the thermal insulation behavior for the biocomposite panels highlighted the fact that they have thermal insulation properties with high values for thermal resistance and global thermal insulation coefficients.
\end{abstract}

Keywords: ligno-cellulosic waste, biocomposites, thermal resistance, thermal insulation

\section{INTRODUCTION}

In Europe the field of energy presents many challenges, such as: high levels of energy prices, security risks affecting producer and transit countries, growing threats posed by climate change, the need for better integration and interconnection in the energy markets, as well as increasing dependence on imports. The Establishment of optimal measures for energy consumption occupies an important place in the economic development of a country, this (energy consumption) being directly proportional to the number of inhabitants [1].

Energy saving is an issue that has now become a major topic of global discussion alongside social, political and economic issues. In generally buildings from Romania have a low degree thermal protection which leads to approximately double energy consumption compared to other EU countries, this having a direct consequence on the high level of pollutant emissions [2].

The analysis of scientific research conducted globally shows that solutions are currently being sought to reduce energy consumption by identifying effective thermal insulation measures. One of the main energy consumers it is represented by buildings and in order to identify effective thermal insulation measures, the following aspects must be taken into account: shading from the surrounding buildings, location, limited space, calculation methods used and the degree of performance of equipment used for heating, hot water and cooling [3].

The main purpose of the use of thermal insulation materials is to reduce the consumption of energy or fuels, necessary for heating or cooling different rooms and at the same time to reduce greenhouse gas emissions.

*Corresponding author, email: nitu_andreea23@yahoo.com

(C) 2021 Alma Mater Publishing House 
Currently the most used thermal insulation materials are: expanded polystyrene, extruded polystyrene, mineral wool and polyurethane. The above-mentioned thermal insulation materials have both advantages, including obtaining a very low heat transfer coefficient and disadvantages such as low fire resistance and low permeability to water vapor [4].

Among the current concerns of scientific researchers is the possibility of using and recovering wood waste or other lingo-cellulosic waste used to obtain thermal insulating composite structures. Waste recycling has many advantages due to the fact that it is an important source of materials and energy, and by capitalizing on the waste, the quantity that was to be treated by storage or incineration is diminished, implicitly the environment is also protected [5]. Sources of recycled cellulose can be used in different fields due to their characteristics: regenerative capacity, mechanical properties, existing large quantity and compatibility with the environment [6]. Any material containing cellulose, lignin or hemicellulose can successfully replace wood particles in a composite material. Therefore, wood-based composites can be replaced by composites made from alternative materials, thus also contributing to the protection of forests [7]. Both wood waste and ligno-cellulosic vegetable waste are an important source of materials needed to obtain biocomposites with thermal insulation properties [8].

Biocomposite materials show a complex evolution over time from the adobe used to build houses to their use in various branches of industry. The main advantage of biocomposite materials is that they can replace materials from non-renewable sources and obtained through an expensive process, due to their superior properties, in particular due to their durability [9].

The paper addresses the comparative analytical determination of thermal insulation behavior for various experimental models made of stratified and hybrid biocomposites of ligno-cellulosic nature. The realization of such biocomposite structures has several advantages, respectively: superior characteristics to conventional materials, low price of biocomposite components and environmental protection [8-11]. The aim of this work is to obtain long-term solutions for the creation of biocomposite structures with thermal insulating properties from waste, which are necessary to create a comfortable climate inside a room, regardless of the season. Whether it is heating the room in winter or cooling the room in summer, energy is consumed to achieve hygrothermal comfort. Therefore, the hygrothermal comfort is closely related to the energy efficiency of the room in the sense that the aim is to obtain a level of comfort with minimal energy consumption, regardless of whether it is a matter of maintaining heat inside the room or a decrease in room temperature, especially in the context of rising global average temperatures as a result of climate change [12-14].

The negative effects of climate change are increasingly felt by the population and consequently it (the population) should be aware of its obligations regarding the responsible consumption of the planet's resources and at the same time the protection of the environment [15].

\section{EXPERIMENTAL SETUP}

The experimental research presented in this paper aims to give solutions for energy efficiency in various rooms by creating biocomposites with thermal insulation properties of ligno-cellulosic waste that can be used to build the walls of those rooms.

Whereas it is currently used as a material for the thermal insulation of various rooms of mineral wool and polystyrene boards [15], this paper seeks to obtain more environmentally friendly and less expensive substitute biocomposite materials [9] by comparative analytical determination of thermal insulation behavior for various experimental models made of stratified and hybrid biocomposites of ligno-cellulosic nature.

The analyzed experimental models present the following characteristics / composition and are illustrated in Figures 1 and 2, as follows:

- $M_{1}$ - obtained from wood waste - fine wood powder with $20 \mathrm{~mm}$ thick formaldehyde resin (MDF), $10 \mathrm{~mm}$ thick extruded polystyrene (PS) polymer core and a transparent adhesive for ultra-adherent thin film bonding POLYMAX / crystal express BISON;

- $M_{2}$ - made of folded solid wood - $20 \mathrm{~mm}$ thick dry beech (PMF), $10 \mathrm{~mm}$ thick extruded polystyrene (PS) polymer core and a transparent adhesive for ultra-adherent thin film bonding-POLYMAX / crystal express BISON; - $M_{3}$ - obtained from wood (OSB) with a thickness of $10 \mathrm{~mm}$ and brick with a thickness of $88 \mathrm{~mm}$; 
- $M_{4}$ - obtained from wood (OSB) with a thickness of $10 \mathrm{~mm}$ and BCA with a thickness of $100 \mathrm{~mm}$; - $M_{5}$ - obtained from wood (OSB) with a thickness of $10 \mathrm{~mm}$ and adobe with a thickness of $100 \mathrm{~mm}$.
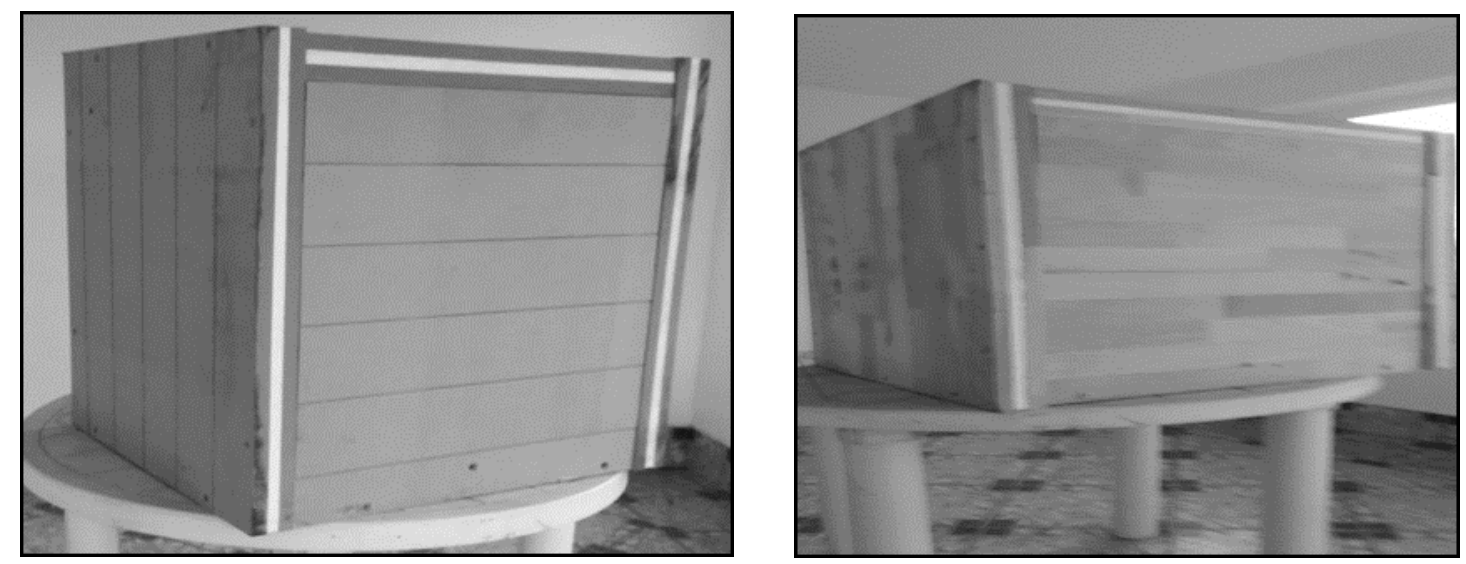

Fig. 1. Experimental models Laminated biocomposite panels of ligno-cellulosic nature (sandwich type): a - model $M_{1}$ (MDF/PS/MDF); b - model $M_{2}$ (PMF/PS/PMF).
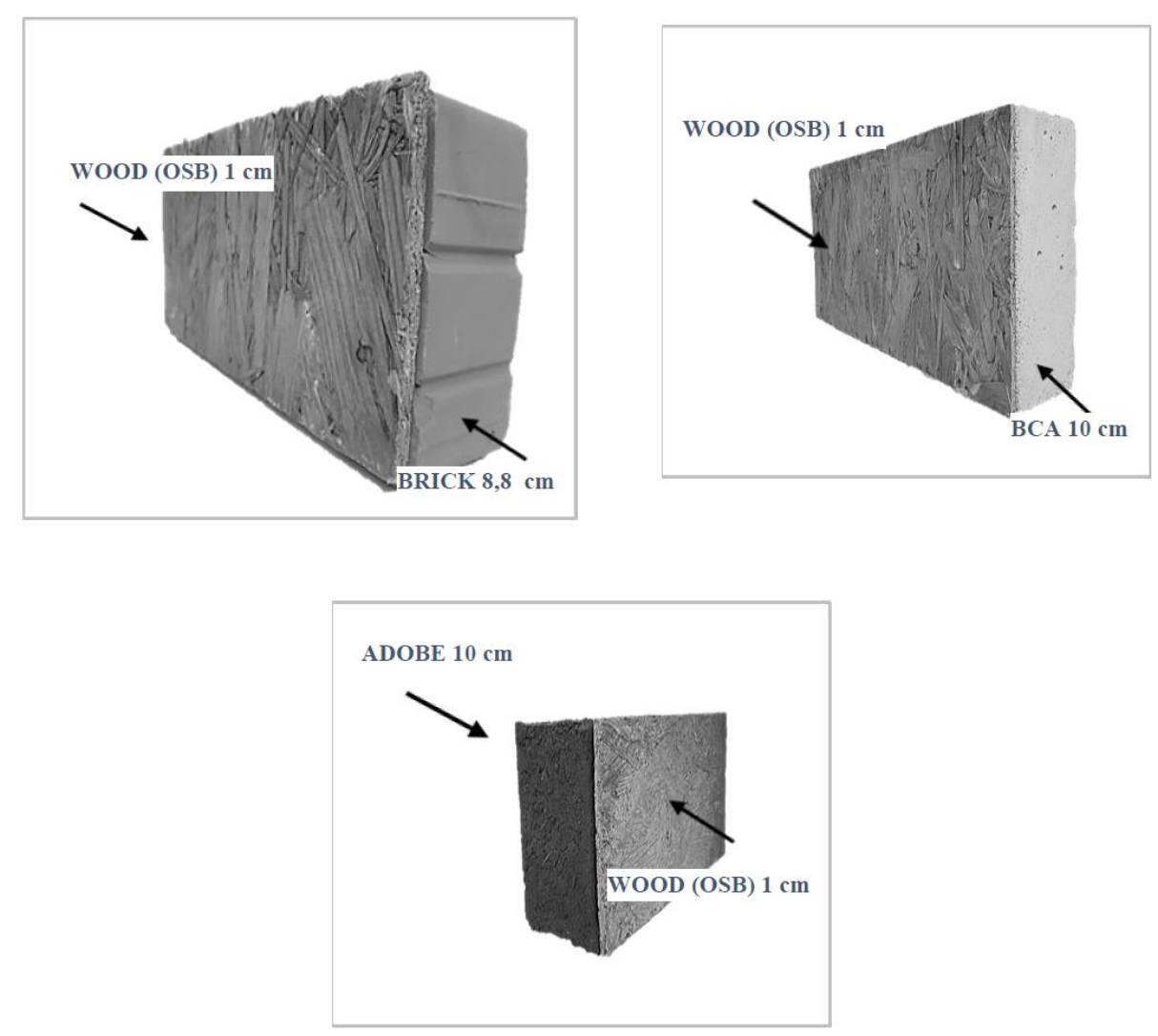

Fig. 2. Experimental models Laminated and hybrid biocomposite structures of ligno-cellulosic nature: a- model $M_{3}$ (wood OSB/brick); b- model $M_{4}$ (wood OSB/BCA); c- model $M_{5}$ (wood OSB/adobe).

For the comparative analytical determination of the thermal insulation behavior for experimental models $\left(M_{1}-M_{5}\right)$ made of stratified and hybrid biocomposites of ligno-cellulose nature was used the calculation methodology for energy efficiency of building structures [13, 16, 17].

The calculation methodology for experimental models $M_{1}$ and $M_{2}$ comprises the following steps for determining the overall thermal insulation coefficient, G: 
- determination of the main dimensional characteristics of $M_{1}$ and $M_{2}$, respectively the surface of the external walls $\left(A_{1}\right)$, the surface of the roof $\left(A_{2}\right)$, the surface of the floor $\left(A_{3}\right)$, the external perimeter $(\mathrm{P})$ and the internal volume (V);

- determination of specific unidirectional thermal resistances, $R_{1, M 1}$ and $R_{2, M 2}\left[\mathrm{~m}^{2} K / W\right]$, by means of the following relation [13]:

$$
R=R_{s i}+\sum \frac{d}{\lambda}+R_{s e}
$$

where: $R_{s i}, R_{s e}$ - internal and external surface thermal resistance $\left[m^{2} K / W\right], \mathrm{d}-$ homogeneous layer thickness $[m], \lambda$-computational thermal conductivity $[\mathrm{W} / \mathrm{mK}]$.

- determination of the global thermal insulation coefficients of each experimental model $G_{1}$ and $G_{2}\left[W / m^{2} K\right]$, by means of the following relation [13]:

$$
\mathrm{G}=\frac{1}{V} \times \sum \frac{A_{a 1,2} \times \tau}{R_{m 1,2}^{\prime}}+0,34 \times \mathrm{n}
$$

where: $V$ - internal volume, $A_{a 1,2}$ - area of the construction element, $\tau$ - outdoor temperature correction factor, $R_{m 1,2}^{\prime}$ - thermal resistance, $n$ - natural ventilation speed of the building.

- determination of the global normed coefficient of thermal insulation of each experimental model $G_{n}\left[W / m^{2} K\right]$, by means of the following relation [13]:

$$
G_{n=\frac{A_{a 1,(2)}}{V}}
$$

where: $A_{a 1,2}$ - area of the construction element, $V$ - internal volume.

The calculation methodology for the experimental models $M_{3}-M_{5}$, construction elements composed of several layers of homogeneous materials, including layers from unventilated air, includes the following relation for the determination of thermal resistance [13]:

$$
R=R_{s i}+\sum R_{s}+\sum R_{a}+R_{s e}
$$

For determining the values of thermal resistance related to the analyzed experimental models, the values of density $\rho$ and conductivity $\lambda$ taken from Norm C107 / 2005 are taken into account and a constant humidity value is used in order not to influence the thermal insulating properties of biocomposites.

\section{RESULTS AND DISCUSSION}

The level of global thermal insulation is appropriate, if condition [13] is met:

$$
G \leq G_{n}\left[W / m^{3} K\right]
$$

From the analytical determinations carried out it results that both experimental models $M_{1}$ and $M_{2}$ meet the condition provided by the legislation in force, as the values obtained for the overall global thermal insulation coefficient of each experimental model $G_{1}$ and $G_{2}$ has a value lower than the value of the global normed thermal insulation coefficient $G_{n}\left[\mathrm{~W} / \mathrm{m}^{2} \mathrm{~K}\right]$. Therefore both experimental models have thermal insulation characteristics with high values for thermal resistance and overall thermal insulation coefficient.

Following the determination of the values of thermal resistance and global thermal insulation coefficients for each experimental model, the following results were obtained, according to Table 1 and Table 2, below. 
Table 1. Values of unidirectional specific thermal resistances $R_{1, M 1}, R_{2, M 2}, G_{1}$ and $G_{2}$ for experimental models of Laminated biocomposite panels of ligno-cellulosic nature (sandwich type) $M_{1}$ and $M_{2}$.

\begin{tabular}{|c|c|c|c|}
\hline $\begin{array}{c}\text { Experimental } \\
\text { model }\end{array}$ & $\begin{array}{c}\text { Unidirectional specific } \\
\text { thermal resistances, } \\
R_{1, M 1} \text { and } R_{2, M 2} \\
{\left[m^{2} K / W\right]}\end{array}$ & $\begin{array}{c}\text { Specific global thermal } \\
\text { insulation coefficient, } \\
G_{1} \text { and } G_{2} \\
{\left[W / m^{2} K\right]}\end{array}$ & $\begin{array}{c}\text { Global normed coefficient of } \\
\text { thermal insulation, } G_{n} \\
{\left[W / m^{2} K\right]}\end{array}$ \\
\hline$M_{1}$ & 2.547 & 41.699 & 105.6 \\
\hline$M_{2}$ & 1.792 & 59.167 & \multirow{2}{*}{. } \\
\hline
\end{tabular}

Table 2. Values of unidirectional specific thermal resistances $R_{3, M 3}, R_{4, M 4}$ and $R_{5, M 5}$ for experimental models of Laminated and hybrid biocomposite structures of ligno-cellulosic nature $M_{3}, M_{4}$ and $M_{5}$.

\begin{tabular}{|c|c|}
\hline $\begin{array}{c}\text { Experimental } \\
\text { model }\end{array}$ & $\begin{array}{c}\text { Unidirectional specific thermal resistances, } \\
R_{3, M 3}, R_{4, M 4} \text { and } R_{5, M 5} \\
{\left[m^{2} K / W\right]}\end{array}$ \\
\hline$M_{3} K / W$ & 0.404 \\
\hline$M_{4}$ & 0.583 \\
\hline$M_{5}$ & 0.413 \\
\hline
\end{tabular}

Analyzing the values obtained by the two experimental models $M_{1}$ and $M_{2}$ it is observed that the model $M_{2}$ obtained a global thermal insulation coefficient slightly higher than the model $M_{1}$ but given the fact hat $\left(M_{1}\right)$ is made of ligno-cellulosic waste it is considered that it can be promoted as a long-term sustainable material.

From the analytical determinations performed it results that the experimental models $M_{3}, M_{4}$ and $M_{5}$ can replace existing materials with thermal insulation properties, but with thicknesses about 4-6 times greater than those of the biocomposites used in the experiment in this paper.

Analyzing the comparative results of unidirectional thermal resistances specific to the experimental models studied, the graphical representation of Figure 3, according to which the thermal insulation behavior of stratified biocomposite structures of ligno-cellulosic nature $M_{1}$ and $M_{2}$ is higher than that calculated for laminated and hybrid biocomposite structures of ligno-cellulosic nature $M_{3}, M_{4}$ and $M_{5}$.

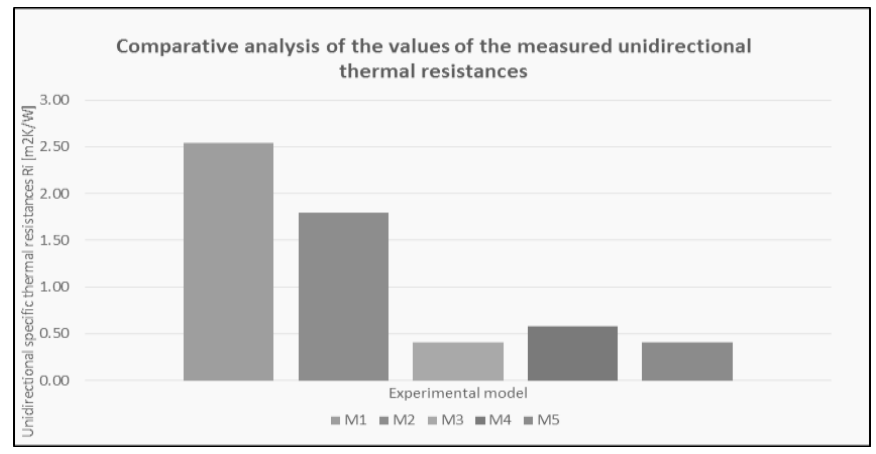

Fig. 3. Graphical representation of the thermal insulation behavior specific to the analyzed biocomposite structures.

The results obtained from the analytical determinations performed, highlight the fact that biocomposites made from ligno-cellulosic waste have thermal insulation characteristics and can be widely used for thermal insulation of various rooms, to be ensure energy efficiency and a high level of comfort with minimum energy consumption.

\section{CONCLUSIONS}

This paper aims to address a topical issue, respectively reducing the amount of ligno-cellulosic waste existing globally by capitalizing on them in the realization of biocomposites with thermal insulating properties and at the same time reducing energy consumption. 
From the evaluation of the thermal insulation behavior of biocomposite plates it resulted that biocomposites made from materials with polymer core and ligno-cellulosic outer faces obtained the highest values for thermal resistance and also an optimal value for the specific global coefficient of thermal insulation, respectively lower than the global normed coefficient thermal insulation. Although the other biocomposites studied in this paper have obtained lower thermal resistance values, they can be used for the thermal insulation of various rooms if they are designed with thicknesses about 4-6 times greater than those of the biocomposites used in this study. Therefore, it can be stated that the resources of renewable raw materials specific to wood or lingo-cellulosic waste, resulting from economic activities represent an alternative for the thermal rehabilitation of different rooms.

Given that satisfactory results have been obtained for the biocomposite structures studied in this experiment, these results are an argument that encourages researchers in the field to try to recover other types of waste for the realization of such biocomposite thermal insulation structures.

\section{REFERENCES}

[1] Purece, C., Analiza asupra utilizarii surselor regenerabile de energie din România, Institutul Naţional Român pentru Studiul Amenajării și Folosirii Surselor de Energie, Energetica, vol. 68, no.9, 2020, p. 417-424.

[2] Marusciac, D., Pleșa, S., Confortul higrotermic și economia de energie la cladirile civile existente, A XI-A Conferință Națională multidisciplinară - cu participare internațională "Profesorul Dorin PAVEL - fondatorul hidroenergeticii românești”, 2011, p. 283-290.

[3] Măgurean, A.M., Analiza performanței energetice a clădirilor nerezidențiale prin tehnici de modelare numerică și inteligență artificială aplicată, Teză de doctorat, Universitatea Tehnică din Cluj-Napoca, 2021.

[4] Mihuț, I., Materiale compozite inovative pentru construcții pe bază de perlit expanat, Proiect de cercetare științifică, Universitatea Tehnică din Cluj-Napoca, 2021.

[5] Nemeş, O., Analiza, modelarea și proiectarea ecologică a materialelor şi structurilor complexe, Teză de abilitare, Universitatea Tehnică din Cluj-Napoca, 2016.

[6] Popa, V.I., Obtaining of nanocellulose, Celuloză și Hârtie, vol. 64, no.3, 2015, p. 3-10.

[7] Coşereanu, C., Compozite din deșeuri agricole și industrial reciclate, Teză de abilitare, Universitatea Transilvania din Brașov, 2015.

[8] Barbu, M.C., Dezvoltarea materialelor composite din lemn şi alte resurse lingo-celulozice, Teză de abilitare, Universitatea Transilvania din Brașov, 2017.

[9] Stanciu, M.D., Terciu, O.M., Curtu, I., Compozite lingocelulozice. Aplicații în industria automobilelor, Ed. Universitatea Transilvania din Braşov, 2014.

[10] Borlea, A., Rusu, T., Ionescu, S., Nemeș, O., Determination of the sound absorption properties of some new composite materials obtained from wastes, Romanian Journal of Materials, vol. 42, no. 4, 2012, p. 405-414.

[11] Bratu, M., Dumitrescu, O., Vasile, O., Ropotă, I., Pascu, L.F., Research on attenuation of sound waves by using panels made of composite materials, Romanian Journal of Materials, vol. 46, no. 1, 2016, p. 121-126.

[12] About climate change. https://www.eea.europa.eu/ro/themes/climate/about-climate-change (15.04.2021).

[13] Normativ privind calculul termotehnic al elementelor de construcție ala clădirilor. Indicativ C107/2005.

[14] Grădinaru, C.M., Șerbănoiu, A.A., Managementul materialelor ecologice de construcții. Analiza utilizării unor agregate ușoare de origine vegetală ca materie primă în producerea betonului, Ed. Bioflux Cluj -Napoca, 2019.

[15] Advantages and efficiency of cellulose insulation. http://www.termocel.ro/sisteme-izolare/avantaje-izolarecu-celuloza/ (15.04.2021).

[16] EN ISO 13789, Thermal performance of buildings - Transmission heat loss coefficient - Calculation method.

[17] EN ISO 7345, Thermal insulation- Physical quantities and definitions. 